\title{
Holocene shoreline displacement in southernmost Spitsbergen
}

\author{
WIESLAW ZIAJA and OTTO SALVIGSEN
}

\begin{abstract}
Ziaja, W. \& Salvigsen, O. 1995: Holocene shoreline displacement in southernmost Spitsbergen. Polar Research 14(3), 339-340.

Three radiocarbon dates on marine organic material from southernmost Spitsbergen are presented, making it possible to compare the Holocene shoreline displacement in this area with that of other areas of Svalbard. The most distinct raised beach feature is the large beach ridge terrace about $10 \mathrm{~m}$ above sea level which most probably is the result of a marine transgression ca. 6500 years ago. Dating of 2700 -year-old laminaria from about $2 \mathrm{~m}$ above sea level demonstrates a small rising of the land during the youngest Holocene.
\end{abstract}

Wieslaw Ziaja, Jagiellonian University, Institute of Geography. Grodzka 64, 31-044 Kraków, Poland; Otto Salvigsen, Norsk Polarinstitutt, Middelthunsgate 29, P.O. Box 5072 Majorstua, N-0301 Oslo, Norway.

A great variety of well-developed raised beaches occur in southernmost Sørkapp Land (Fig. 1). This note deals with marine deposits and features from the middle- and late-Holocene. The main objective is to demonstrate an eastward increase in shoreline displacement in southernmost Spitsbergen. Other forms of relief and Quaternary deposits have been described by Wójcik \& Ziaja (1993).

Three samples of marine organic material collected from Sørflya (Fig. 1) in 1991 have been dated (Table 1). Two dates are from the large beach ridge terrace about $10 \mathrm{~m}$ above sea level. This prominent geomorphological feature can be followed continuously for a distance of many kilometres (Fig. 1). A whale bone found on top of the ridge terrace $10-20 \mathrm{~cm}$ below the surface revealed an age of $6465 \pm 105$ yrs B.P. (T-10860). An identical age was obtained by dating a laminaria layer in the ridge, $9.5 \mathrm{~m}$ above sea level and $0.7 \mathrm{~m}$ below the surface, $6440 \pm 55 \mathrm{yrs}$ B.P. (T-10859). The latter is a confirmation of a former dating of laminaria from the same site, $6580 \pm 160$ yrs B.P. (Gd-6583) reported by Wójcik \& Ziaja (1993). A few kilometres to the northeast from this site (Bettybukta), a whale bone found $9.5 \mathrm{~m}$ above sea level revealed the age $6580 \pm 50 \mathrm{yrs}$ B.P. (SRR-2174 in Forman 1990).

Dating of a layer of laminaria from the left bank of the river near to Skjemmeneset and Sørkapphytta, about $2 \mathrm{~m}$ above sea level, resulted in the age of $2715 \pm 85$ yrs B.P.

The radiocarbon dates presented here are in good accordance with the shoreline diagram for northwestern Sørkapp Land presented by Salvigsen \& Elgersma (1993). Their conclusion was that the Holocene transgression there was completed about 7500 years ago and was followed by a relatively stable sea level for about 2000 years. The transgression resulted in a large beach ridge

Table 1. Radiocarbon dates from southernmost Spitsbergen, Svalbard

\begin{tabular}{llclll}
\hline Lab. No. & Field No. & Elevation $(\mathrm{m})$ & Site & Material & Age ${ }^{14} \mathrm{C}$ yrs B.P. \\
\hline T-10861 & $(1)$ & 0.2 & Skjemmeneset & laminaria & $2715 \pm 85$ \\
T-10860 & $(2)$ & 10 & Aurodden & whale bone & $6465 \pm 105$ \\
T-10859 & $(3)$ & 9.5 & Mathiasbreen & laminaria & $6440 \pm 55$ \\
Gd-6583 & Wojcik \& Ziaja 1993 & 9.5 & Mathiasbreen & laminaria & $6580 \pm 160$ \\
\hline
\end{tabular}




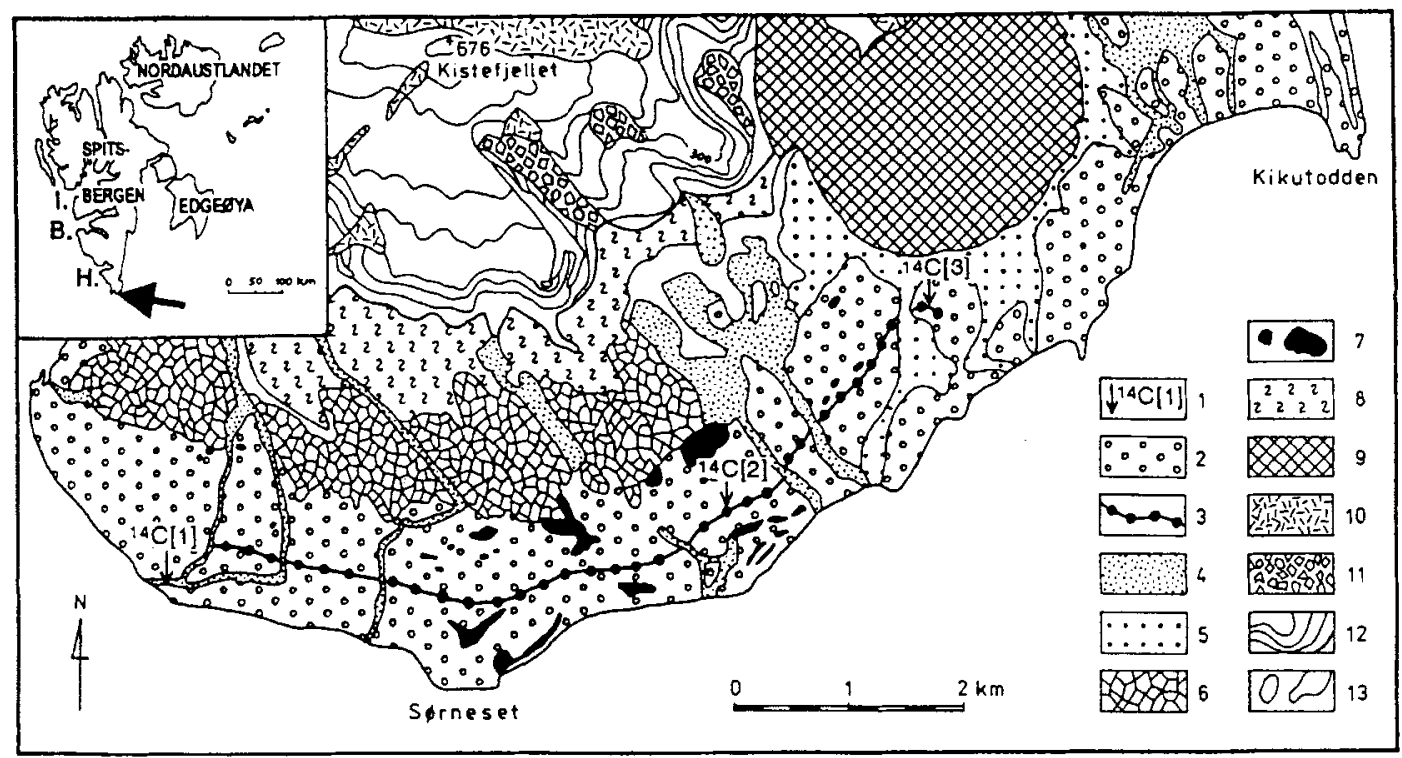

$1 .=$ Isfjorden $\quad H .=$ Hornsund $B .=$ Bellsund

Fig. 1. Location map showing the main geomorphologic features of southernmost Sørkapp Land. 1. Three sites of radiocarbon dated material indicated by field nos. ${ }^{14} \mathrm{C}[1]$ (Skjemmeneset). ${ }^{13} \mathrm{C}[2]$ (Aurodden), and ${ }^{1+} \mathrm{C}[3]$ (Mathiasbreen, forefield) (see also Table 1). 2. Holocene terraced coastal plains. Sorflya and Grunnvägsletta, up to $19 \mathrm{~m}$ a.s.l. 3. The main heach ridge terrace, $10 \mathrm{~m}$ a.s.l. 4. Fluvial deposits and alluvial fans. 5. Glaciofluvial extramarginai deposits. 6. Old skerries of Trollstabbane and Sørflyrabbane with fragments of raised marine terraces $20-40 \mathrm{~m}$ a.s.1. 7. Lakes. 8 . Solifluction sediments. 9. Marginal zones of glaciers. 10. Glaciers and perennial snow. 11. Moraines and rock glaciers. 12. Rocky slopes with a thin cover of weathered material. 13. Rocky surfaces of raised cliffs. terraces and former skerries. The inset map shows Isfjorden (I). Bellsund (B) and Hornsund (H).

terrace which can be followed along the western coast from Sørkapp to north of Isfjorden (Landvik et al. 1987; Salvigsen et al. 1990; Salvigsen et al. 1991).

The top level of this ridge shows some variations in altitude from $10 \mathrm{~m}$ between Isfjorden and Bellsund (Landvik et al. 1987) to $7 \mathrm{~m}$ on the coast south of Hornsund (Salvigsen \& Elgersma 1993). The crest level of the large beach ridge in southernmost Sørkapp Land has been repeatedly determined by a Paulin altimeter in such a way that the uncertainty is less than $\pm 1 \mathrm{~m}$. We can therefore conclude that the crest level there is about $3 \mathrm{~m}$ higher than the crest level in northwestern Sørkapp Land. This indicates that the southernmost part of Spitsbergen also shows an increased shoreline displacement from the west towards the east during the last 6500 years. We think that the pattern of relative uplift is mainly caused by different isostatic depression during the last glaciation. Thus, our observations indicate a heavy Late Weichselian glaciation in the sea east of southernmost Spitsbergen.

\section{References}

Forman. S. L. (comp.) 1990: Svalbard Radiocarbon Date List I. Occasional Paper No. 47. INSTAAR, Boulder. 48 pp.

Landvik. J. Y.. Mangerud, J. \& Salvigsen, O. 1987: The Late Weichselian and Holocene shoreline displacement on the west-central coast of Svalbard. Polar Res. 5 n.s., 29-44.

Salvigsen, O., Elgersma. A., Hjort, C. Lagerlund, E. Liestøl, O. \& Siensson, N.-O. 1990: Glacial history and shoreline displacement on Erdmannflya and Bohemanflya, Spitsbergen. Svalbard. Polar Res. 8, 261-273.

Salvigsen, O.. Elgersma, A. \& Landvik, J. Y. 1991: Radiocarbon dated raised beaches in northwestern Wedel Jarlsberg Land. Spitsbergen. Svalbard. Wyprawy Geograficzne na Spitsbergen, 9-16.

Salvigsen, O. \& Elgersma. A. 1993: Radiocarbon dating of deglaciation and raised beaches in north-western Sørkapp Land, Spitsbergen, Svalbard. Zesz. Nauk. UJ, Prace Geogr. 94. 39-48.

Wójcik. A. \& Ziaja, W. 1993: Relief and Quaternary of southern Sorkapp Land, Spitsbergen. Pol. Polar Res. 14(3). 293-308. 